and motives of the participation of the peasant population in the partisan parties, the consequences of the rebel movement for all levels of the peasantry.

Purpose. The purpose of the study is to identify the factors that promoted the transforming the social struggle of the peasantry into a political component of the peasant revolution during the peasant revolts in the Kyiv region in the summer 1918.

Results. The initiative and leadership role in the organization of revolts in the Kyiv region belonged to the hetmans of the Free Cossacks of Zvenigorod district, which supported the district military transport officer M. Pavlovskiy. In May 1918, with the participation of I. Kapulovskiy, Yu. Tyutyunnik, 18 partisan parties were formed with a total of 25 thousand people. The peasants were handed over 10 thousand shoulder arms and many other weapons.

The officers military unites of the Ukrainian government and the German army began to disarm the peasants, forcing them to comply with the legislation of the Ukrainian State: to return landowners the property they had been looted before, to use repressions. Local actors of the socialist revolutionary party and M. Pavlovskiy called up the peasants to revolt against the hetman (M. Pavlovskiy himself immediately left Kyiv region). The Hetmans of the Free Cossacks began a peasant revolt without an integrated staff, supreme leadership, they did not coordinate their actions with the leaders of political parties in Kyiv and the leaders of the UPR (there were only the rumors about their participation). Each military staff had its own political program. The rural population of the Kyiv province took an active part in the armed struggle: the peasants could raise a military group up to 15,000 people, and could go to their quarters in a few days. The participation in the revolt was taken by peasants of all ages and social groups. In general, the revolt involved 30-40 thousand people. Due to the repression of power, the great human and material losses of the rebels, the liberation struggle became a criminal offense and failed.

Originality. For the first time the revolt in Kyiv province in the summer 1918 was considered in the context of the peasant revolution. The reasons for defeating the peasant revolt in the Kyiv region are specified.

Conclusion. Zvenigorod-Taraschanskiy revolt of 1918 was a spontaneous implementation of the political programme of the peasant revolution (the participation of the peasantry in the assumption of power), which was developed by the socialists revolutionaries and the social democrats in the early twentieth century. The failure of the revolt confirmed the Bolsheviks conclusions about the weak revolutionary capabilities of the peasants: disorganization and inactivity, spontaneity and local character of outrages. The lack of responsibility of the local military-political leaders towards the peasantry, the unpreparedness of the revolt, allows us to characterize the performances in the Kyiv region in the summer of 1918 as a political misadventure. The positive changes that were determined by the political patterns of the peasant revolution in Dnieper Ukraine in 1918 have become the following: self-organization of peasant population, formation of the political requirements, and change of social conscience.

Key words: peasantry, revolt, Free Cossacks, Zvenigorod district, Taraschanskiy district, political programme, peasant revolution.
UDC94(477): [329(477): 332.2.021.012.33]“"1917/1921”(045) DOI: $10.31651 / 2413-8142-2019-21-14-20$

S. Kornovenko

doctor of historical sciences, professor of the department of intellectual Property and civil law disciplines of the Bohdan

Khmelnytsky National University of Cherkasy

N. Zemzulina

doctor of historical sciences, professor of the department world history and international relations of the Bohdan Khmelnytsky University of Cherkasy

\section{UKRAINIAN AGRARIANISM AS AN OPTION OF EASTERN EUROPEAN AGRARISM IN POLITICAL PROGRAMS OF THE UKRAINIAN NATIONAL PARTIES OF THE PERIOD OF THE UKRAINIAN REVOLUTION}

Revolutionary upheavals in Europe in the early twentieth century had a decisive influence on the socio-political life of European countries, led to the emergence of previously unknown phenomena. The agrarianism became one of them in the first third of the twentieth century. It was most widely used in Bulgaria, Poland, Romania and Czechoslovakia. The authors proved that in the early twentieth century the Ukrainian version of Eastern European agrarianism also existed. It was especially pronounced during the Ukrainian Revolution of 1917 - 1921, which, among other things, had the peasant nature. Its representatives on the Ukrainian soil were, on the one hand, non-governmental, party, political figures and organizations, on the other - the peasantry of Ukraine as an active subject of the peasant revolution in 1917 - 1921. In particular, Ukrainian agrarianism was presented as an option of Eastern European agrarianism. the provisions of the Ukrainian Democratic-Agrarian Party (hereinafter referred to as UDAP), the Ukrainian People's Community (hereinafter - UPC), the All-Ukrainian Union of Agrarians-Owners (Peasants) (hereinafter - AUAO), and the Ukrainian People's Party (hereinafter - UPP).

Keywords: Eastern European agrarianism, Ukrainian agrarianism, peasant revolution, Ukrainian revolution, peasantry.

The statement of the issue. The first third of the twentieth century is a unique period of European history. Although it is relatively short in time, it is extremely rich in multifaceted socio-cultural transformations that radically changed the political map of Europe, the world, and largely determined the course of world history in the first half of the twentieth century. These changes concerned not only the revolutionary upheavals experienced by the European continent, but also the emergence of previously unknown phenomena, new subjects in both international politics and the domestic political life of many European countries.

The changes in issue were the result of long-term systemic crises caused by the authorities' inadequate response to modernization. Among the factors behind the revolutionary upheavals in Europe in the early twentieth century one of the determinants was agrarian. The peasantry of Europe was dissatisfied with its socioeconomic situation, its legal status. Agriculture, as a leading sector of the economy of most Eastern European

\footnotetext{
* The article is written in accordance with the state budget theme "Ukrainian Revolution (1917-1921 gg.): The peasant factor" (state registration number $0118 \mathrm{U} 003864$ ).
} 
countries, needed an effective agrarian policy designed to significantly improve not only the peasants' material wealth but also their legal status. Socio-political upheavals in Europe in the early twentieth century also led to the search for an alternative for bourgeois-capitalist or Bolshevik-communist model of socio-political development. This option became the "third path of development" represented by Eastern European agrarianism. Therefore, Eastern European agrarianism in general and Eastern European in particular became one of the phenomena of European history of the first third of the twentieth century, and the peasantry became an active subject in the domestic political life of Eastern European countries. Accordingly, agrarian issue became a priority direction of domestic government policy, and the agrarianism became the political doctrine of Eastern European countries.

Research analysis. Questions consistent with the topic of our research are partially reflected in Ukrainian and foreign historiography [1-10]. Researchers have mainly focused on aspects relating to the nature and content of Eastern European agrarianism, the realization of the so-called "third" path in some Eastern European countries, the unfolding of the peasant revolution in the post-imperial Russian space, the formation of the agrarian's ideology in V. Lypynsky's works and its Eastern European agrarianist context. At the same time, taking into account the phenomenality of Eastern European agrarianism, the Ukrainian Revolution of 1917 - 1921, the determining factor of which was peasant, it is relevant to study Ukrainian agrarianism of that period as an option of Eastern European agrarianism of the first third of the twentieth century.

Purpose. The authors aims to investigate the phenomenon of Ukrainian agrarianism during the Ukrainian Revolution of 1917 - 1921 as an option of Eastern European agrarianism presented in the political programs of the Ukrainian national parties. The subjects of the study were the political programs of those parties, which referred to the peasantry as an active subject of national state formation, the social basis of Ukrainian statehood. In agreement with K. Galushko's reasoning, we were interested, first of all, in those political parties whose programs emphasized "on the political separatism" of the peasants and on the particularity of the peasant "third way". In our opinion, apart from the UDAP, agrarianist programs of political parties such as UPC, AUAO, UPP.

The statement of the basic material. Contemporary historical and scientific literature has established the view that agrarianism originated in Germany in the works of G. Ruland, A. Schaeffle. Subsequently it spreads to the territory of France, represented by the concept of J. Melin. At the end of the nineteenth and early twentieth centuries agrarianism spreads into Eastern Europe - Poland, Bulgaria, Romania, Czechia and Slovakia (later Czechoslovakia) [8, 178]. Among the reasons for the emergence of agrarianism, researchers are unanimous in that it was driven by the following factors: first, the agrarian nature of the economies of Eastern European countries; second, the severity of the agrarian issue in these countries; third, the numerical dominance of the peasantry over other segments of the population of Eastern European countries; fourth, the increased public interest in agrarian issues in general and the peasantry in particular. This is emphasized by K. Galushko [8], G. Matveev $[9,3]$ and other scientists.

In our opinion, in addition to the above, the causes of agrarianism were the following. First, the conflict between industrial and agrarian civilizations, which clearly began to manifest itself in the second half of the nineteenth - early twentieth centuries in the conditions of modernization of agrarian-industrial countries and economies and their transformation into industrialagrarian or approximated to them with corresponding transformation of values. One example is the socioeconomic and socio-political models of the Russian and Austro-Hungarian empires, which in the second half of the nineteenth and early twentieth centuries have undergone similar modernizations. The orbits of the modernization processes were the Czechia, Slovakia, Poland, Ukraine, etc. - future independent entities of international law, countries representing Eastern European agrarianism, which at that time were part of the Romanov and Habsburg empires, respectively. We believe that the advancement of the industrial civilization of the Western sample to the Eastern European agrarian space has provoked a defensive reaction on the part of the largest social strata of Eastern European countries the peasantry. It became East European agrarianism of the first third of the twentieth century presented with Polish, Bulgarian, Czechoslovakian, Romanian, Ukrainian, etc. options.

Secondly, the development of political culture of the agrarian nations, which at that time were Polish, Bulgarian, Czechoslovakian, Romanian, Ukrainian, etc. The political cultures of Polish, Bulgarian, Czechoslovakian, Romanian, Ukrainian, etc. peasants have undergone a modernization of values. In our opinion, there has been an essential socio-cultural shift in the collective and individual political culture and consciousness of the peasants - the transition from an indifferent political culture and consciousness to an effective one.

Third, the objective laws of the development of the agrarian civilization itself, the formation in its bowels of a qualitatively different peasantry. In the case of Ukraine - the peasant-ideoman - an active subject of history [11]. Ukrainian peasantry in the early twentieth century was qualitatively different from both the urban proletariat and the peasantry of previous centuries, formed under fundamentally new conditions of post-serfdom reality. The qualitative difference was the absence of serfdom not only as a legal status. First of all, there is an absence of serfdom as a way of being, doing business, thinking style, etc. It was a generation brought up under the conditions of capitalization of agriculture, industrialization, transformation of the rural community - all that is considered to be the modernization of the second half of the nineteenth - beginning of the twentieth centuries in the Russian Empire. The peasants began to gradually realize themselves as a separate community of the then socio-cultural imperial space. The unifying value was the "Idea of the Land", its distribution on fair, in their understanding, principles. These considerations are in line with the position of other modern researchers [12]. We are also impressed by A. Gordon's reasoning that the liquidation of serfdom made the peasant a "rational agent" in the interpretation of classical political economy and sober sense. The psychology of the peasant became more resilient to those new phenomena 
that actively spreaded into peasant existence. It is difficult to disagree with V. Piskun in the fact that the liquidation of serfdom gave impetus to modernization, changed the consciousness of the peasant, strengthening in him the feelings of the owner [13].

Therefore, we state that the emergence of East European agrarianism was caused by objectivesubjective-subjective factors. Their combination gave impetus to the formation of Eastern European agrarianism - the phenomenon of the first third of the twentieth century. Considering the area of its spreading, the territorial features and features of socio-economic and socio-political development of Eastern European countries, we can reasonably distinguish its options: Polish, Bulgarian, Czechoslovakian, Romanian, Ukrainian, etc.

In our opinion, in the broad sense of the East European agrarianism of the first third of the twentieth century - a holistic socio-cultural phenomenon, the phenomenon of Eastern European history of the first third of the twentieth century, caused by the objectivesubjective-subjective factors which is the object of knowledge. In a narrow sense, Eastern European agrarianism is a system of peasant-centric representations of different subjects of the socio-cultural space of Eastern Europe in the first third of the twentieth century and their practical implementation. Specifying a narrower understanding of Eastern European agrarianism in the first third of the twentieth century in the context of our object of study, we state that it is a system of political ideas about the peasantry as an active subject of history, a representative of the "third" way, the social basis of statehood.

There are all reasons to say that Ukrainian agrarianism became ideologically-theoretically and structurally formed phenomenon in Ukraine in the conditions of the revolutionary reality of 1917 - 1921. Its representatives, in particular, were political parties. We believe that Ukrainian agrarianism of that period reflected the agrarian nature of Ukrainian society. Its agrarian nature in no way is a basis for understanding Ukrainian society as less valuable, "underdeveloped", etc., compared to similar Eastern European, Western European or other societies. Ukrainian agrarianism during the Ukrainian Revolution of 1917 - 1921 witnessed the transition from the indifferent political culture and consciousness of the Ukrainian peasantry to the active, the agrarian nature of the Ukrainian nation.

First of all, the Ukrainian agrarianism is presented in the Materials for the Program [Ukrainian Democratic Political Party] (hereinafter - Materials) and in the Outline on the Program of the Ukrainian Democratic-Agrarian Party (hereinafter - the Outline). Authorship of "Outlines" belongs to V. Lypynsky [14; 15]. The Materials raised the question that political forces in the Ukrainian political life of the period of the Ukrainian Revolution clearly outlined neither socialist nor non-socialist tendencies. In fact, the organizing committee of the Ukrainian Democratic Party proclaimed a third political force, by which it positioned itself [16, 253].

V. Lypynsky's "Outline" describes not only the political priorities of the Ukrainian Democratic-Agrarian Party, but also prominently reproduces the leading social leadership of the Ukrainian Democratic Republic. First of all, the name of this political force reflects its agrarian nature, because 'as an agrarian party, we will ensure that the agrarian part of Ukrainian democracy, in the process of creating our free political life, has a position that corresponds to its number ( 85 per cent of all people) and strength' [17, 257]. The author of the "Outline", and in fact, in our opinion, "The Peasant Manifesto" writes confidently that political power in Ukraine "must primarily belong to the representatives of the Ukrainian peasantry, and the city must not dictate its will to the Ukrainian countryside. Ukraine is the land of agrarians, and the Ukrainian state must become the state of agrarians. Standing on this ground, our Party will use all means to increase the political, economic and cultural strength of the Ukrainian peasantry" [17, 257 - 258].

In this way, he clearly distinguishes two Ukrainian worlds: the village and the city. The village should become free from the dictates of the city and the social foundation of the Ukrainian state, which is peasant in nature. At the level of the program of the political party, the understanding of the peasantry is crystallized not only as the keeper of the cultural and spiritual values of the people, but as a full-fledged, active subject of history, national state-building. The understanding of the agrarian nature of Ukrainian society by V. Lypynsky is clear. We believe that this is a de facto reference to the Ukrainian peasant state and, accordingly, the Ukrainian peasant nation. Reasonable is the reasoning of R. Vetrov, S. Zborets about the fact that "Lypynsky views the peasant not as a farmer with his ethnocultural attributes, but as a conscious citizen of the state, the owner who produces the most important value for his wealth and independence - the bread" $[18,136]$.

The provisions of "Outline" relating to educational, cultural, economic spheres are also saturated by the agrarianism. The sections of the program document clearly state that "in the field of education and culture, our party as an agrarian party, in addition to general democratic demands, aims to spread education and culture in the countryside as much as possible... In order to do so, we will seek to establish in villages all sorts of schools... the universities, specially designed for peasants. The work of a rural teacher in a free agrarian Ukraine must be particularly honored, and his financial status must be so well-placed that the best of our intelligent forces will be attracted to this magnificent and difficult work" [17, 159-260].

The economic model of agrarian Ukraine as a state, from the point of view of the Ukrainian DemocraticAgrarian Party (hereinafter referred to as the UDAP), will have nothing to do with the chaos of the "private capitalist economy". It will be based on fundamentally different principles: "the interest of the private entrepreneur... should be limited... by the widest possible state control over the national economy, and from below - by the organization and association of the people-producing masses. Therefore, our party will stand for ... the greatest development of the democratic cooperative movement in all its forms and options" [17, 261]. In this way, a third alternative economic model the cooperative, was proposed. According to the party, it was the most suitable for the main producer of material goods - the peasantry. It harmoniously combined private and public interests; there was no excessive capitalist urge and socialist dissolution of the individual in the collective.

The agrarian issue wasn't out of focus of the UDAP's political program. However, understanding of 
its essence and ways of solution was based on principles other than those of other parties. First of all, the difference was that for UDAP "Free agrarian Ukraine" was the "the land of highly developed, intensive farm agriculture" [17, 262]. Thus, they viewed the agrarian issue as a component of governmental pro-peasant agrarian policy, and the peasant - a citizen whose landed private property is the basis of the Ukrainian state. The party vision of Ukrainian village prospects was the third way of development. It was understood as the placement throughout Ukraine of "farms of the working Ukrainian peasantry, on which the Ukrainian agrarian, united in powerful cooperative societies, extracts from his native land his and his family's work with the maximum that it can give" [17, 262].

The members of the UDAP in "the Outline" drew attention to another detail that favorably differentiated their vision of the nature and ways of solving the agrarian issue. For them, Ukraine "belongs to the lands of Western European agricultural culture". In view of this fact, the party members stressed that they would "fight against all Russian projects of agrarian reform, based on the alien for us primitive psychology of the "community" (all redistribution and allotments "per capita") and the extensive system of agriculture ("cutting" of the land to the triple peasant economy)» $[17,263]$. In this way, representatives of the UDAP first of all saw in the Ukrainian peasantry the social basis of Ukrainian statehood; secondly, they clearly understood that the Ukrainian peasant was a unique self-sufficient subject, qualitatively different from the Russian one; thirdly, the decision of the Ukrainian agrarian issue should be based on European-Ukrainian principles that contribute to the development of high-tech industry with preservation of the identity of the Ukrainian peasantry as the embodiment of cultural and national values. Other options based on other principles, according to UDAP members, are "reactionary, because they lead back to the lower stages of this development and threaten a large decline in productivity and crop capacity of the land" $[17,263]$.

Agrarianism also marked the political program of the Ukrainian People's Community (hereinafter - UPC). The sources of its formation connected with P. Skoropadsky, who, according to his memoirs, wanted to lead a democratic party that "should have led to compromises between property and the poor, and between the Great Russians and Ukrainians" $[18,133]$. By creating the party and developing its program, P. Skoropadsky and his associates aimed to substantiate that 'the Ukrainian movement is not German propaganda, but living in the people ... that the party ... does not define the form of government, but clearly defends democracy and preservation of property' $[18,126]$. Democracy, among other things, in the understanding of the party's founder, is a "strong shift in the agrarian issue" $[18,126]$. P. Skoropadsky connected with the peasantry the future of the Ukrainian State, being a supporter of the "third way", and considered democratic reforms an instrument for achieving this goal. The future Hetman believed that 'our Ukrainian is an individualist; he does not need any socialization. He is strongly against it. According to the hetman, among the slogans of the revolution, most understandable to the peasantry, is the idea of the land' $[18,50]$. He was aware that 'it is necessary to carry out truly healthy democratic reforms, not socialist ones, but democratic ones. We do not have socialism in the people, and therefore, if there is one, then among the numerous, torn apart people group of intellectuals ... I have no doubt ... that any socialist experiments ... would immediately lead to the whole country during 6 weeks would be the prey of all-devouring Moloch-bolshevism. Bolshevism, by destroying the culture, would turn our beautiful country into a dried up plain, where capitalism would eventually settle ... the almighty God, in whose feet the people would wallow and crawl' [18, $145-146]$.

V. Kochubey, M. Voronovych, V. Lyubynsky and others who actively cooperated with P. Skoropadsky on the 1st Ukrainian Corps were active party activists of the UPC. According to P. Doroshenko, at the basis of its activities, UPC 'put a compromise on social issues, democratization of the state system within the limits harmless to the state power, and Ukrainization of Russified cultural strata of Ukrainian citizens, but by a slow involvement of these strata in cultural and state Ukrainian work' [19, 22 - 23]. In G. Papakin's quite right opinion, it contained two basic components: "uniting all owners against socialist experiments and trying to avoid the extremes of "fierce capitalism" [20, 145].

The above considerations of P. Skoropadsky have been adequately reflected in the political program of UPC. In our opinion, it, like P. Skoropadsky's views, was clearly agrarianist. With the future head of the Ukrainian State, O. Lupakov, B. Butenko, O. Paltov, A. Rzepetsky, I. Dusan and other Ukrainian intellectuals, who are not indifferent to the fate of their homeland, have been involved in the development of "The Program of the Ukrainian People's Community" (hereinafter referred to as the Program). The choice of the Third Way was declared by the 12th item of the political program of the party. It stated that neither the monarchy, which was unable to meet the diverse needs of the people, nor detached from the life theories of maximalists which had no reason in real life, was not acceptable to the UPC. But a state building was acceptable, based on the will of the people, taking into account the historical experience of state building, its historical-political traditions [21, 209]. Thus, the source of power of the Ukrainian State was announced the people. Considering that 85 per cent were peasants, they were understood to be the social basis of this state.

The Program also described the priorities of domestic policy. Its main purpose was to ensure the proper conditions for the development of private initiative and entrepreneurship, the expression and realization of the "creative forces of the people", above all the peasantry as the most numerous strata of Ukrainian society. The key to this was the guarantee by the state of "truly reasonable freedom". The latter refers to the protection of the life, property, legal rights and interests of a person against oppression by both the state and unlawful interference by outsiders [21, 209].

UPC clearly defined the agricultural character of Ukraine in its programmatic provisions. By modern language - an agrarian type of society. Accordingly, issues of land tenure / land use, land tenure, legal subjectivization of the peasantry, improvement of its material well-being were of paramount importance. Their decision was subordinated to the end goal - "for the benefit of the agricultural population of Ukraine". Subjectivization was interpreted as guaranteeing the inviolable property right, which "corresponds to the original and unchanged convictions of the Ukrainian- 
agrarian" [21, 209-210]. Taking care of the material wellbeing of the agrarian families, its improvement, the program envisaged measures aimed at clear legislative regulation of the sale and purchase of land, and elimination of speculation in this case. The agrarians and their families were to receive land in the size that would guarantee their safe lives and sufficient use of their own labor. The priority in land acquisition belonged to the Cossacks and the disadvantaged, who "who did not spare their lives, breast-shielded Ukraine from external and internal enemies" [21, 210].

UPC members argued that all forms of socioeconomic self-organization of the peasantry should be supported by the state. In particular, the finance agency had to take special care of the development of cooperatives, mutual loan companies, loan and savings partnerships, etc. The cooperation of the UPC parties, as well as the members of the UDAP, considered the basis of the economic model of the future Ukrainian state $[21,211]$.

Therefore, the program of the agrarian changes and the social basis of the Ukrainian State was determined by the Ukrainian-agrarian. The above convinces the agrarianist nature of the programmatic provisions of UPC, the agrarianist content of the beliefs of P. Skoropadsky.

The agrarianist ideology was peculiar to both the All-Ukrainian Union of Agrarians-Owners (Peasants) (hereinafter - AUAO) and the Ukrainian People's Party.

In October 1918, AUAO was formed. It includes some members of the Kyiv Regional Union of Landowners, headed by M. Kovalenko, who disagrees with the programmatic foundations of the All-Russian Union of Landowners (hereinafter referred to as the "AUL") [22, 463]. On 20 October 1918, their platform was presented in "The Memorandum of the Owners-Agrarians and Cossacks of All Ukraine". The relatively short volume of the document clearly outlines the peasant-centric orientations of this political organization. The peasantagrarian stratum was proclaimed the sole and solid foundation of Ukrainian statehood. The peasantry was guaranteed equal civil rights and freedoms. The principle of private property is inviolable. The ultimate goal of agrarian reform is to satisfy the socio-economic interests of the broader peasant-agrarian strata. Land tenure, despite inviolability of private property rights, is limited. Regulatory policy regarding land tenure is implemented by the state, represented by the Land Bank. The instrument of implementation of agrarian reform was the compulsory purchase of land from large landowners. The parceled land was transferred to the peasants who needed it for some payment through the Land Bank [23, 466]. Thus, in its program of state building, the AUL made a clear reference to the peasantry, the social basis of national statehood. The socio-political and socioeconomic model of the state was peasant-centric, agrarian.

In May 1919, the Ukrainian People's Party (hereafter UPP) was formed. It was intended to include UDAP and AUAO. However, such unification did not take place and the newly formed party was formed only of the members of the AUL [246 470]: M. Chudnov-Bohun, K. Krasiuk, M. Bayer, M. Arnaut and others. Its programmatic principles were based on the AUAO provisions, in particular on agrarianism. At the same time, they were supplemented and expanded in "The Program of the Ukrainian People's Party" (hereinafter - the
Program). Party members emphasized that national statebuilding should be based on the unity of all "economically healthy and creative elements of the people". However, the "broad masses of small and medium peasantry" are leading in this process. In this regard, satisfaction of peasant interests and needs is a priority. This was subordinated to the financial and economic policy of the state. Among other things, its implementation ensured the economic development of the country, its protection against the "exploitation by foreigners" [25, 474-475].

In that way, the UPP rejected the exploitation, considering the non-exploitative model of the state. The agrarianist nature of the party's program provisions contained those parts of the party program that concerned the economy and tactics of party activity. In our opinion, they clearly state the content of the nonexploitative model of Ukrainian statehood, emphasize the agrarian nature of Ukrainian society and its economy. Cooperation is treated as an optimal socio-economic institute, which, on the one hand, provides the population with the necessary products, and on the other, minimizes the exploitation factor. In the context of Eastern European agrarianism, it was understood as a socio-economic institute that 'strengthens the economic position of our people and makes it more organized in the fight against the exploitation by foreigners' $[25,487]$.

According to the Party members, the peasantry is 'the main creative economic stratum in Ukraine; the main basis of the national economy is farming, the productivity of which is based on the average and small land ownership, with the help of associations and agricultural cooperatives...' $[25,475]$. In the Resolution of the Main Board of the Ukrainian People's Party of 7 September 1919 , the role of the peasantry in the national statebuilding was outlined more clearly and fully. The document stated that 'the basis, the center of the creative forces in Ukraine, is the peasantry - the agrarians and national-industrial elements ... and only these elements can be a solid basis for the future of the Ukrainian state and national idea, because the proletariat and the great bourgeoisie in Ukraine, from the national point of view, are alien or indifferent to Ukrainian national-state competitions. ... And if the economic interests of this class are not linked to national-political interests, then Ukrainian national affairs and statehood will be long suppressed by hostile forces of neighbors, all of whom have a clearly defined nationalist-imperialist color' $[25$, 495].

Given the agrarian nature of Ukrainian society, the relevance of the agrarian issue, the need to improve the socio-economic situation and socio-legal status of the peasantry, it was envisaged to implement agrarian reform. These improvements were supposed to be achieved by "raising the agro-culture, as well as securing the nationalstate rights of the Ukrainian people, who are the owner of their land and the manager of their economy" [25, 487].

According to UPP members, agrarian reform should be peasant-centric and based on the following principles: 1. Protection of small and medium-sized land ownership; 2 . Abolition of large land tenure; 3 . Forcible redemption by the state of the excess land from the large landowners and its transfer on preferential terms to the landless peasantry for cultural housekeeping. This approach was justified by the UPP members' financial interests of the state, as well as the impossibility of social confrontation 
in the countryside; $[25,487] 4$. Transfer of specific, treasury and monastery lands to the state fund; 5 . Determination of the standard of land for sale in the amount of 25 acres; 6 . By providing amelioration credit support to agricultural cooperatives; 7. State support for farms and agricultural cooperatives [25, 476].

The conclusions. Therefore, there is sufficient reason to state that in the conditions of the Ukrainian Revolution of 1917 - 1921, Ukrainian agrarianism took place as an option of Eastern European agrarianism. It was represented in the programmatic provisions of UDAP, UPC, UPP, AUAO. They referred to the peasantry as the state builder, social basis of statehood, the "third" path of development. This combines Ukrainian agrarianism with Eastern Europe, which is evidence that the Ukrainian Revolution of 1917 - 1921 had a distinct European context.

\section{Bibliography:}

1. Корновенко С. Революційні потрясіння початку XX ст. аграрне законодавство країн Центральної та Південносхідної Європи / С. Корновенко, Н. Земзюліна // Український селянин. - 2018. - Вип.19. - С. 45 - 49.

2. Fareniy I. (2019). The peasant revolution in theoretical views and political practice of Ulyanov-Lenin. Schidnoievropeisyi Istorychnyi Visnyk [East European Historical Bulletin], 10, 58-65.

3. Фареній І. Про правомірність концепції «Великої селянської революції» В.П. Данилова / І. Фареній // Український селянин. - 2014. - Вип. 14. - С. 162 - 166.

4. Holec R. Agrarian democracy as an attempt at a third way in Central European transformation [Agrarna demokracia ako pokus o tretiu cestu Stredoeuropskej transformacie] Historicky Casopis. Volume 59, Issue 1, 2011, Pages 3 - 32.

5. Bernstein $\mathrm{H}$. The peasant problem in the Russia revolution(s), 1905 - 1929. Journal of Peasant Studies, 2018 $45(5-6)$, Pages $1127-1150$

6. Sumpf A. The Russian peasant revolution [les revolutions du paysan russe]. Vingtieme Siecl: Revue Historie, 2017, 135 (3), Pages $102-116$

7. Finkel E., Gehlbach S., Kofanov D. (Good) Land and Freedom (for Former Serfs): Determinants of Peasant Unrest in European Russia, March-October 1917. Slavic Review, 2017, 76 (3), Pages $710-721$

8. Галушко К. «Хліборобська ідеологія» В. Липинського у системі східноєвропейського аграризму / К. Галушко // Український історичний збірник. - 2000. - № 2. - С. 164 200

9. Матвеев Г. «Третий путь»? Идеология аграризма в Чехословакии и Польше в межвоенный период / Г. Матвеев. - М. : Изд-во Московского университета, 1991. - 240 с. 10. Галушко К. Консерватор на тлі доби: В'ячеслав Липинський і суспільна думка європейських «правих» / К. Галушко. - К.: Темпора, 2002. - 288 с.

11. Корновенко С. Суб'єктний складник аграрного питання як одна з передумов Української революції 1917 - 1921 pp. / С. Корновенко // Український історичний журнал. 2017. - № 4. - С. 83 - 94.

12. Простаков С. Сетевое крестьянское восстание в 1902 г. / С. Простаков. [Електронний ресурс]. - Режим доступу: http://rusplt.ru/setevoe-krestyanskoe-vosstanie-v-1902-godu12119.html

13. Марченя П. Крестьянство и власть в истории России XX века: по итогам международного круглого стола / П. Марченя, С. Разин, И. Ионов. [Електронний ресурс]. Режим доступу: http:www.civisbook.ru

14. Турченко Ф. В'ячеслав Липинський - ідеолог Української демократичної хліборобської партії / Ф. Турченко, Н. Заліська // В'ячеслав Липинський. Історико- політологічна спадщина і сучасна Україна. - К. ; Філадельфія, 1994. - С. 171 - 181.

15. Гай-Нижник П. Липинський та УДХП в теорії і практиці українського державотворення і політичного націоналконсерватизму (1900 - 1920 рр.) / П. Гай-Нижник // Гілея. - 2018. - Вип. 129. - С. $305-322$.

16. Матеріали до програми // Липинський В. Твори, архів, студії / ред. Я. Пеленський. - К. - Філадельфія, 1994. - Т. 1: Студії. В'ячеслав Липинський: історико-політологічна спадщина і сучасна Україна. - С. 253 - 254.

17. Липинсьий В. Нарис програми Української демократичної хліборобської партії / В. Липинський // Липинський В. Твори, архів, студії / ред. Я. Пеленський. К. - Філадельфія, 1994. - Т. 1: Студії. В'ячеслав Липинський: історико-політологічна спадщина і сучасна Україна. - С. $254-266$.

18. Скоропадський П. Спогади / П. Скоропадський. - К., Філадельфія, 1995. - 493 с.

19. Дорошенко Д. Історія України, 1917 - 1923.: в 2 т. / Д. Дорошенко. - К. : Видавництво «Темпора», 2002. - Т. 2. Українська Гетьманська Держава 1918 року. - 352 с.

20. Папакін Г. Українська народна громада і Павло Скоропадський навесні 1918 р. / Г. Папакін // Наукові записки ІПіЕНД ім. І.Ф. Кураса НАНУ. - 2008. - Вип. 39. C. $129-150$.

21. Программа Украинской народной громады // Геращенко T.C. Українська народна громада / Т. Геращенко // Вісник Київського державного лінгвістичного університету. Серія «Історія, економіка, філософія» / ред. Ю.І. Терещенко. К.: КДЛУ, 2000. - Вип. 4. - С. $208-213$.

22. Любовець О. Всеукраїнський союз хліборобіввласників (селян) / О. Любовець // Українські партії революційної доби 1917 - 1920 рр.: Нариси історії та програмні документи. - К. : Парламентське вид-во, 2018. C. $463-469$.

23. Меморандум Хліборобів-власників і козаків усієї України // Любовець О. Всеукраїнський союз хліборобіввласників (селян) / О. Любовець // Українські партії революційної доби 1917 - 1920 рр.: Нариси історії та програмні документи. - К. : Парламентське вид-во, 2018. C. $463-469$.

24. Любовець О. Українська народна партія / О. Любовець // Українські партії революційної доби 1917 - 1920 рр.: Нариси історії та програмні документи. - К. : Парламентське вид-во, 2018. - С. 470 - 496.

25. Програма Української народної партії // Любовець О. Українська народна партія / О. Любовець // Українські партії революційної доби 1917 - 1920 рр.: Нариси історії та програмні документи. - К. : Парламентське вид-во, 2018. - C. $474-496$.

\section{References:}

1. Kornovenko, S. (2018). Revolutionary upheavals of the early twentieth century: agrarian legislation of the countries of Central and Southeastern Europe. Ukrainian Peasant, 19, 45 49. [in Ukrainian].

2. Fareniy, I. (2019). The peasant revolution in theoretical views and political practice of Ulyanov-Lenin. Schidnoievropeisyi Istorychnyi Visnyk. East European Historical Bulletin, 10, 58-65.

3. Fareniy, I. (2014). On the legitimacy of the V. P. Danilov's concept of the "Great Peasant Revolution" Ukrainian Peasant, 14, 162 - 166. [in Ukrainian].

4. Holec, R. (2011). Agrarian democracy as an attempt at a third way in Central European transformation. Historicky Casopis, 59, 1, 3-32.

5. Bernstein, H. (2018). The peasant problem in the Russia revolution(s), 1905 - 1929. Journal of Peasant Studies, 45 (5 6), $1127-1150$ 
6. Sumpf, A. (2017). The Russian peasant revolution. Vingtieme Siecl: Revue Historie, 135 (3), $102-116$

7. Finkel, E., Gehlbach, S. \& Kofanov, D. (2017).(Good) Land and Freedom (for Former Serfs): Determinants of Peasant Unrest in European Russia, March-October 1917. Slavic Review, 76 (3), 710 - 721 .

8. Galushko, K. (2000). V. Lypynsky's “Agrarian Ideology” in the System of Eastern European Agrarianism. Ukrainian Historical Collection, 2, 164 - 200. [in Ukrainian].

9. Matveev, G. (1991). "The third way"? The ideology of agrarianism in Czechoslovakia and Poland in the interwar period. Moscow, 240. [in Russian].

10. Galushko, K. Conservative against the backdrop of the day: Vyacheslav Lypynsky and the public opinion of European "rightists", 288. [in Ukrainian].

11. Kornovenko, S. (2017). The subject component of the agrarian issue as one of the prerequisites of the Ukrainian Revolution of 1917 - 1921. Ukrainian Historical Journal, 4 , 83 - 94. [in Ukrainian].

12. Prostakov, S. Network peasant uprising in 1902. Source: http://rusplt.ru/setevoe-krestyanskoe-vosstanie-v-1902-godu12119.html [in Russian].

13. Marchenya, P. The peasantry and power in the history of Russia of the twentieth century: following the results of the international round table. Source: http:www.civisbook.ru [in Russian].

14. Turchenko, F. (1994). Vyacheslav Lypynsky is an ideologist of the Ukrainian Democratic Agrarian Party. Vyacheslav Lypynsky. Historical and political heritage and modern Ukraine. Kyiv - Philadelphia, 171 - 181. [in Ukrainian].

15. Guy-Nyzhnyk, P. (2018). Lypynsky and UDAP in the Theory and Practice of Ukrainian State-Building and Political National-Conservatism (1900 - 1920). Gileya, 129. 305 - 322. [in Ukrainian].

16. Materials to the Program. (1994). Lypynsky V. Works, archives, studios. Kyiv ; Philadelphia, Book. 1. Studios. Vyacheslav Lypynskyi: Historical and Political Heritage and Modern Ukraine, 253 - 254. [in Ukrainian].

17. Lypynsky, V. (1994). The Outline of the Program of Ukrainian Democratic-Agrarian Party. Lypynsky V. Works, archives, studios. Kyiv ; Philadelphia, Book. 1. Studios. Vyacheslav Lypynskyi: Historical and Political Heritage and Modern Ukraine, 254 - 266. [in Ukrainian].

18. Skoropadsky, P. (1995). Memoires. Kyiv ; Phyladelphia, 493. [in Ukrainian].

19. Doroshenko, D. (2002). History of Ukraine, 1917-1923, 2, Kyiv, 352. [in Ukrainian].

20. Papakin, G. (2008). Ukrainian People's Community and Pavlo Skoropadsky in the spring of 1918. Scientific notes of I. F. Kuras IPIEND of NASU,39, 129 - 150. [in Ukrainian].

21. The Program of Ukrainian People's Community (2000). T. Gerashchenko. Ukrainian People's Community. Bulletin of the Kyiv State Linguistic University. History, Economics, Philosophy Series. Kyiv: KSLU, 4, 208 - 213. [in Russian]. 22. Liubovets O. (2018). All-Ukrainian Union of AgrariansOwners (Peasants). Ukrainian Revolutionary Parties of 1917 - 1920: Essays on History and Programming Documents. Kyiv, 463 - 469. [in Ukrainian].

23. Memorandum of the Agrarians-Owners and Cossacks of the Whole Ukraine. (2018). Liubovets O. All-Ukrainian Union of Agrarians-Owners (Peasants). Ukrainian Revolutionary Parties of 1917 - 1920: Essays on History and Programming Documents. Kyiv, 463 - 469. [in Ukrainian].

24. Liubovets, O. (2018). Ukrainian People's Party. Ukrainian Revolutionary Parties of 1917 - 1920: Essays on History and Programming Documents. Kyiv, 470 - 496. [in Ukrainian]. 25. The Program of Ukrainian People's Party (2018). Ukrainian People's Party. Ukrainian Revolutionary Parties of 1917 . 1920: Essays on History and Programming Documents. Kyiv, 474 - 496. [in Ukrainian].
С. Корновенко, Н. Земзюліна

\section{УКРАЇНСЬКИЙ АГРАРИЗМ ЯК ВАРІАНТ СХІДНОЄВРОПЕЙСЬКОГО АГРАРИЗМУ В ПОЛІТИЧНИХ ПРОГРАМАХ УКРАЇНСЬКИХ НАЦІОНАЛЬНИХ ПАРТІЙ ПЕРІОДУ УКРАЇНСЬКОЇ РЕВОЛЮЦІї}

Постановка проблеми. Суспільно-політичні потрясіння в Свропі на початку XX ст. спричинили пошук альтернативної буржуазно-капіталістичній чи більшовицько-комуністичній моделі суспільнополітичного розвитку. Такою моделлю став «третій шлях розвитку», репрезентований східноєвропейським аграризмом упрограмах низки політичних національних партій. Зважаючи на це, одним із феноменів європейської історії першої третини XX ст. загалом та східноєвропейської зокрема став східноєвропейський аграризм, а активним суб' єктом внугрішньополітичного життя східноєвропейських країн - селянство. Відповідно до цього пріоритетним напрямом внутрішньої урядової політики став аграрний, політичною доктриною східноєвропейських країн - аграризм.

Автори статті ставлять за мету дослідити феномен українського аграризму періоду Української революції 1917 - 1921 рр. як варіанту східноєвропейського аграризму, представленого в політичних програмах українських національних партій.

Основні результати дослідження. Появу східноєвропейського аграризму спричинили об'єктивно-суб'єктивно-суб'єктні чинники. Їхнє поєднання дало поштовх до формування східноєвропейського аграризму - феномену першої третини XX ст. Зважаючи на ареал його поширення, за територіальною ознакою та особливостями соціальноекономічного й суспільно-політичного розвитку східноєвропейських країн, є підстави розрізняти такі його варіанти: польський, болгарський, чехословацький, румунський, український тощо.

Є всі підстави говорити про те, що в умовах революційної дійсності 1917 - 1921 рр. в Україні ідейнотеоретично і структурно сформованим явищем став український аграризм. Його репрезентантами, зокрема, були політичні партії. Вважаємо, що український аграризм означеного періоду віддзеркалював аграрний характер українського суспільства. Його аграрність жодною мірою не є підставою для розуміння українського суспільства як меншовартісного, «недорозвиненого» тощо, порівняно 3 аналогічними східноєвропейськими, західноєвропейськими чи іншими соціумами. Український аграризм часів Української революції 1917 - 1921 рр. засвідчив перехід від індиферентної політичної культури й свідомості українського селянства до дієвої, аграрний характер української нації, що формувалася.

Висновки. В умовах Української революції 1917 1921 рр. мав місце український аграризм як варіант східноєвропейського аграризму. Він був представлений упрограмних положеннях УДХП, УНГ, УНП, ВСХВ. У них йшлося про селянство як державного будівничого, соціальну основу державності, «третій» селянський шлях розвитку. Це поєднує український аграризм із східноєвропейським, є свідченням, що Українська революція 1917 -1921 pр. мала виразний європейський контекст.

Ключові слова: східноєвропейський аграризм, український аграризм, селянська революція, Українська революція, селянство. 